$\mathcal{E}_{\text {Iransport Forum }}^{\text {International }}$

\title{
Evolution of Metropolitan Airports in Japan
}

Air Development in Tokyo and Osaka

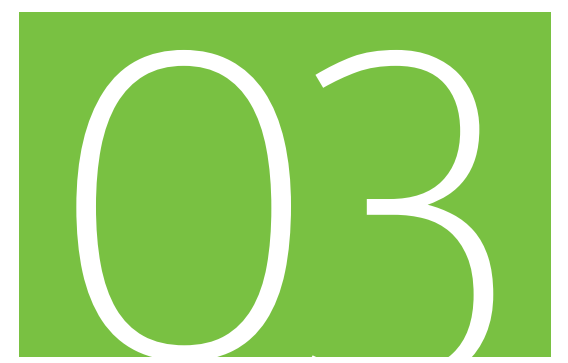

Discussion Paper 2013•03

Katsuhiro Yamaguchi

Visiting Researcher, Graduate School of Public Policy, University of Tokyo,

Visiting Fellow, OECD/ITF 


\title{
International Transport Forum
}

\section{Evolution of Metropolitan Airports in Japan}

\author{
Airport Development in Tokyo and Osaka
}

Discussion Paper No. 2013-3

Prepared for the Roundtable on

Expanding Airport Capacity under Constraints in Large Urban Areas

(21-22 February 2013, Paris)

\section{Katsuhiro Yamaguchi*}

Visiting Researcher, Graduate School of Public Policy, University of Tokyo, Visiting Fellow, OECD/ITF

\footnotetext{
* Currently serves as Executive Officer in charge of corporate strategy at New Kansai International Airport Company, Ltd (NKIAC), and has experience as government official of Ministry of Land, Infrastructure, Transport and Tourism (MLIT) since 1983 and as Professor of Graduate School of Public Policy, University of Tokyo from 2005 to 2008. It should be noted that the view expressed in the paper is of personal observation and does not represent that of the organization.
}

February 2013 


\section{THE INTERNATIONAL TRANSPORT FORUM}

The International Transport Forum at the OECD is an intergovernmental organisation with 54 member countries. It acts as a strategic think-tank, with the objective of helping shape the transport policy agenda on a global level and ensuring that it contributes to economic growth, environmental protection, social inclusion and the preservation of human life and well-being. The International Transport Forum organises an annual summit of Ministers along with leading representatives from industry, civil society and academia.

The International Transport Forum was created under a Declaration issued by the Council of Ministers of the ECMT (European Conference of Ministers of Transport) at its Ministerial Session in May 2006 under the legal authority of the Protocol of the ECMT, signed in Brussels on 17 October 1953, and legal instruments of the OECD.

The Members of the Forum are: Albania, Armenia, Australia, Austria, Azerbaijan, Belarus, Belgium, Bosnia-Herzegovina, Bulgaria, Canada, Chile, China, Croatia, the Czech Republic, Denmark, Estonia, Finland, France, FYROM, Georgia, Germany, Greece, Hungary, Iceland, India, Ireland, Italy, Japan, Korea, Latvia, Liechtenstein, Lithuania, Luxembourg, Malta, Mexico, Moldova, Montenegro, the Netherlands, New Zealand, Norway, Poland, Portugal, Romania, Russia, Serbia, Slovakia, Slovenia, Spain, Sweden, Switzerland, Turkey, Ukraine, the United Kingdom and the United States.

The International Transport Forum's Research Centre gathers statistics and conducts co-operative research programmes addressing all modes of transport. Its findings are widely disseminated and support policymaking in Member countries as well as contributing to the annual summit.

\section{Discussion Papers}

The International Transport Forum's Discussion Paper Series makes economic research, commissioned or carried out at its Research Centre, available to researchers and practitioners. The aim is to contribute to the understanding of the transport sector and to provide inputs to transport policy design. The Discussion Papers are not edited by the International Transport Forum and they reflect the author's opinions alone.

The Discussion Papers can be downloaded from: www.internationaltransportforum.org/jtrc/DiscussionPapers/jtrcpapers.html

The International Transport Forum's website is at: www.internationaltransportforum.org For further information on the Discussion Papers and other JTRC activities, please email: itf.contact@oecd.org

This document and any map included herein are without prejudice to the status of or sovereignty over any territory, to the delimitation of international frontiers and boundaries and to the name of any territory, city or area. 


\section{TABLE OF CONTENTS}

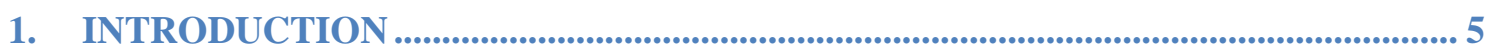

2. OVERVIEW OF JAPAN AND THE AIR TRANSPORT MARKET ...................... 6

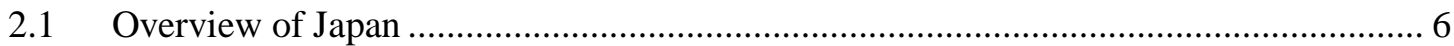

2.2 Development of air transport and airports in Japan .................................................... 7

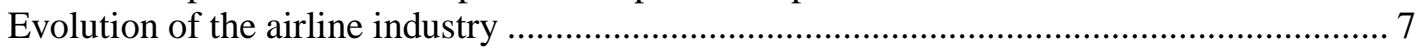

Introduction of new airlines and further deregulation..................................................... 8

Liberalisation in the international air transport market ..................................................... 8

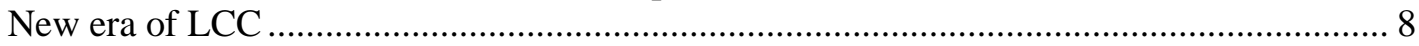

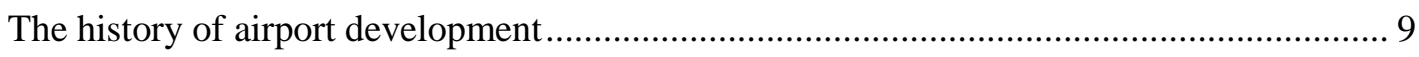

3. BRIEF HISTORY OF AIRPORT DEVELOPMENT IN TOKYO AND OSAKA .... 10

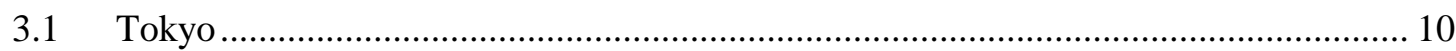

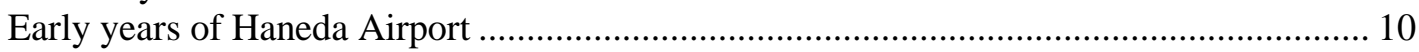

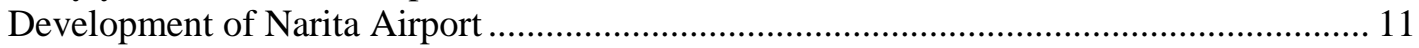

Haneda Airport expanding towards the bay area .............................................................. 13

Road to re-expansion and re-starting international flights at Haneda Airport ...................... 13

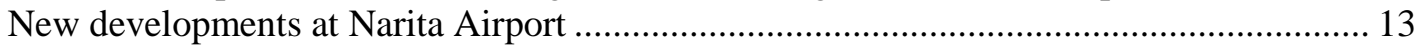

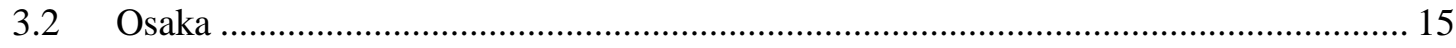

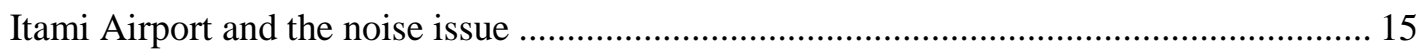

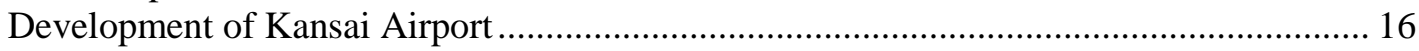

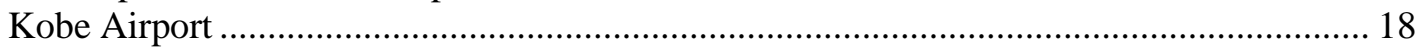

4. KEY FACTORS AFFECTING AIRPORT DEVELOPMENT

IN LARGE URBAN AREA . .......................................................................... 19

4.1. Basic nature of airport development in metropolitan area ........................................... 19

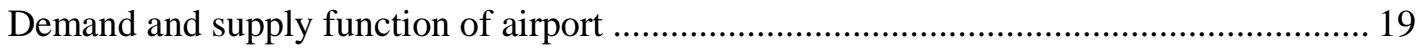

Large three-dimensional space needed to accommodate airport........................................ 19

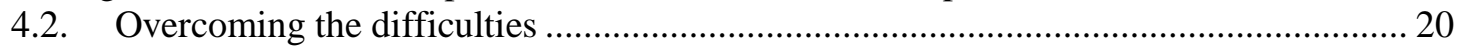

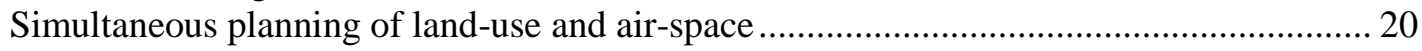

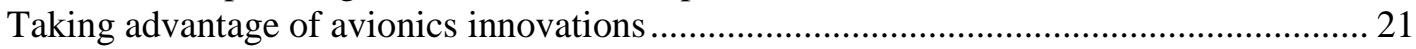

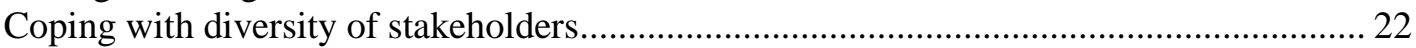

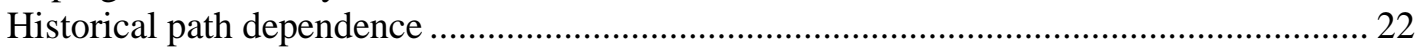

5. IMPLICATIONS FOR FUTURE AIRPORT DEVELOPMENT

IN LARGE URBAN AREA ................................................................................. 24

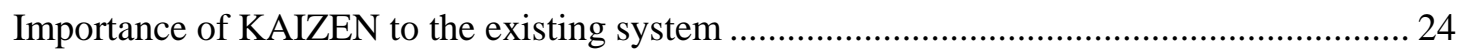

Stimulating local interest groups by competitive forces among airports................................. 24

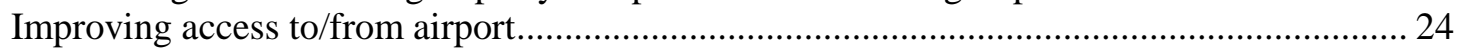

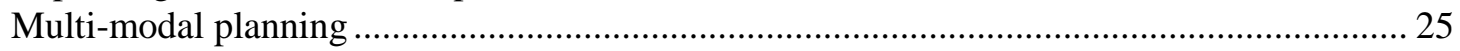

Considering use of price mechanism at congested airports .................................................. 25

6. CONCLUDING REMARIKS ............................................................................ 26 



\section{INTRODUCTION}

If one is asked to give an appraisal of airport development in metropolitan areas in Japan, an unsparing critic may not esteem it highly for three reasons. One, because planning for the secondary airport at Tokyo and Osaka was initiated too late to match growth in demand. Two, due to untimely planning, the original airport was exasperated with the noise issue by the time the search for the location of the secondary airport had begun. As a consequence, the location of the secondary airport had to be situated far from the city centre. Three, because improvements to access transport, to overcome the airport's distant location, were not planned thoroughly enough and have taken too much time to be completed, both the out-of-pocket costs and access time are still unsatisfactory.

Advocates, on the other hand, may be supportive because, considering that both tremendous urban growth and the advent of air transport arose simultaneously in the 1960 s and it was literally impossible to plan ahead of time, air transport demand has been met to a certain degree. As we stand today, Tokyo's two airports, for instance, accommodate approximately 100 million passengers annually, domestic and international combined, which is comparable to the three major airports in London or New York.

In an endeavour to review what has happened and afford prospects of what we see ahead in airport development in Japan's metropolitan areas, this paper covers airport development in Tokyo and Osaka; inter alia, Haneda Airport and Narita Airport in the Greater Tokyo area and Itami Airport, Kansai Airport and Kobe Airport in the Greater Osaka area. The rest of the paper is organized as follows. First, after an overview of Japan and the air transport market, a brief history of airport development in Tokyo and Osaka is presented. Second, key factors affecting airport development in large metropolitan areas are examined. Third, implications for future airport development in large urban areas are discussed. The paper sums up with concluding remarks. 


\section{OVERVIEW OF JAPAN AND THE AIR TRANSPORT MARKET}

\subsection{Overview of Japan}

Japan has 338 thousand square metres of land, out of which 121 thousand square metres are arable. There is an estimated 6832 square kilometres of arable land in the metropolitan areas ${ }^{1}$ of Greater Tokyo and 3690 square kilometres in that of Greater Osaka.

Of the 128 million population, 33 million ( $26 \%$ of total) and 17 million ( $13 \%$ of total) live in Greater Tokyo and Greater Osaka respectively. The population growth rate had been double-digit until the 1970 s but has slowed down since then ${ }^{2}$. According to Demographia ${ }^{3}$, Tokyo-Yokohama is the largest urban area in the world and Osaka-Kobe-Kyoto the twelfth largest.

Both Greater Tokyo and Greater Osaka have outgrown other areas of Japan in population size. In Greater Tokyo and Greater Osaka there are $26 \%$ and $13 \%$ of Japan's total population living on $5.6 \%$ and $3.0 \%$ of Japan's total arable land, respectively. As such, population density in these metropolitan areas is more than 4500 per square-kilometre ${ }^{4}$.

Figure 1 shows that high economic growth was achieved in Japan until 1970, moderate growth during the $70 \mathrm{~s}$ and $80 \mathrm{~s}$, and a slowdown with the burst of the economic bubble in the early 90s. During these years, the economic sector shifted from agriculture to manufacturing and then to the service sector. An agglomeration effect has caused economic activities to be concentrated in urban areas. The four prefectures where Greater Tokyo ${ }^{5}$ and Greater Osaka 6 are located represent $32 \%$ and $14 \%$ of total national GDP, respectively.

1. Urban Employment Area (UEA) defined by Kanemoto, Y., and K. Tokuoka (2002) is used as "metropolitan area" in this paper. "Greater Tokyo" and "Greater Osaka" shall mean UEA of Tokyo 23 Wards, Yokohama, Saitama and Chiba combined, and UEA of Osaka, Kyoto and Kobe combined, respectively.

2. Total population peaked out in 2004.

3. $8^{\text {th }}$ Annual Edition: Version 2, July 2012.

4. Population density is calculated by UAE population and arable land size.

5. Tokyo, Yokohama, Saitama and Chiba.

6. Osaka, Kyoto, Hyogo and Nara. 
Figure 1. Population and GDP of Japan

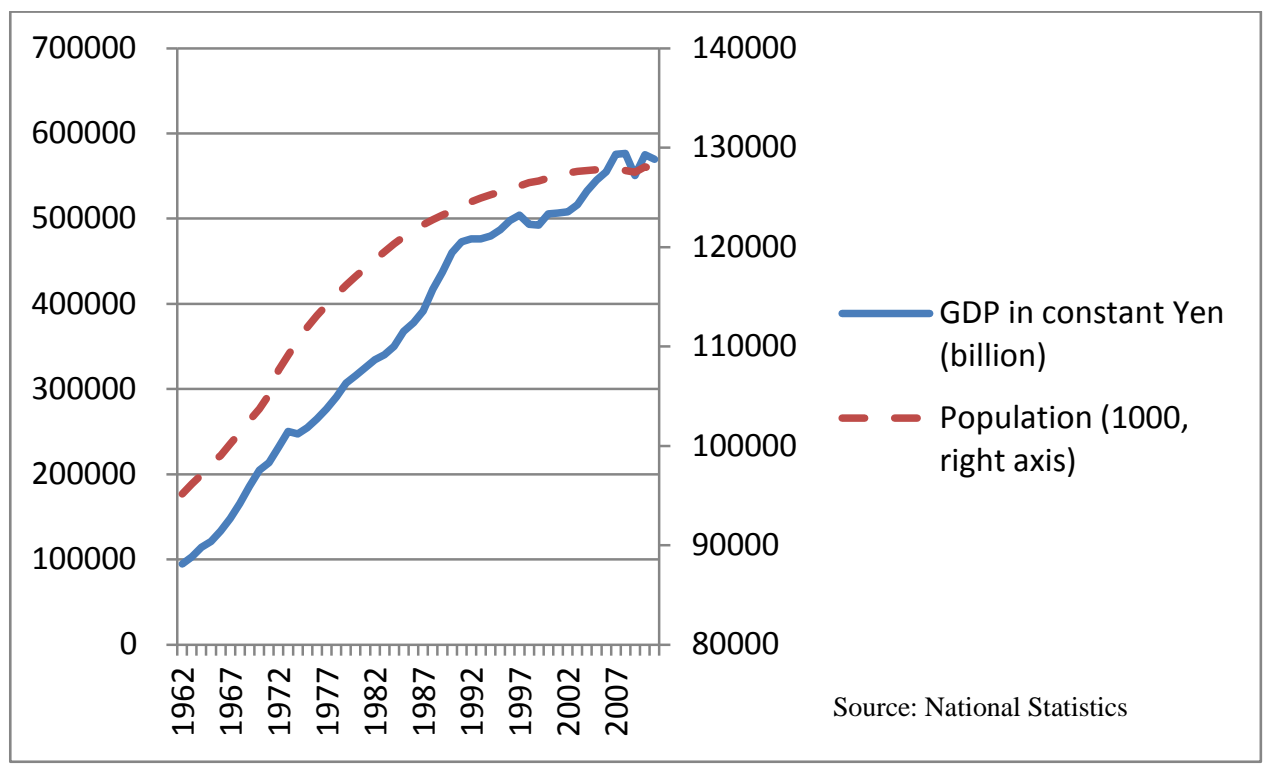

In recent years, Japan has faced a number of challenges: deflation, an aging society, the high appreciation of the Yen and shocks from the Tohoku Earthquake and the Tsunami in 2011. The high-speed transport system is a key factor for facilitating productivity gains and inter-regional market integration, as well as for promoting leisure activities. It is thus at the top of the policy agenda of the national growth strategy. Ueda et al. (2005) identify the significant benefits of Haneda Airport's re-expansion and Yamaguchi (2007) attempts to capture the macro-economic impact of accessibility improvements from development of air transport in Japan.

\subsection{Development of air transport and airports in Japan}

\section{Evolution of the airline industry}

Civil aviation resumed service in 1951. In 1953, Japan Air Lines (JAL) was established and assigned to operate on international and domestic trunk routes. A number of other airlines were to operate on local domestic routes. As the demand for aviation increased, airline competition became severe and a framework to secure fair competition became increasingly necessary. In the early 70 s excessive competition was warded off and the service domain of each airline was designated from the perspective of co-existence and co-prosperity; i.e. JAL on international and domestic trunk routes, All Nippon Airways (ANA) on domestic trunk and local routes, Japan Air Systems [JAS, ex-Toa Domestic Airlines (TDA)] on domestic local routes. Industrial activity was conducted for more than ten years under this so-called $45 / 47^{7}$ framework.

In the 1980s, rapid growth both in international and domestic aviation was achieved. In 1985, the Transport Policy Council reviewed the operating framework of the aviation industry and, based on its recommendations, the 45/47 framework was abolished by the Cabinet in December 1985. A new policy was introduced to promote the increasing number of airlines operating on routes with large numbers of passengers. The new

7. $45 / 47$ stands for 1970 and 1972 in Japan's Showa era. 
aviation policy of 1985 also included the introduction of airlines other than JAL onto the international aviation market and the complete privatization of JAL.

\section{Introduction of new airlines and further deregulation}

In 1996, the incumbent airlines took advantage of the deregulation and effectively raised the fares on trunk routes. This sparked criticism, and two new airlines, Skymark Airlines and Hokkaido International Airlines (AIR DO) were established in 1998. Apart from subsidiaries of the major three companies, these were the first new entries in 35 years.

By the end of the $20^{\text {th }}$ Century, supply/demand regulation policy was totally abolished. Airfare regulation was also deregulated from approval to prior notification. With regard to the most congested airports, such as Haneda and Itami, a slot allocation rule for domestic services was adopted, subject to review every five years and based on pre-set allocation criteria. New airline start-ups have been introduced since the turn of this century. Most of these airlines, however, have more or less been affiliated to one of the major airlines.

Since the turn of the century, the market has been volatile. The 9/11 terrorist attack in 2001, the Iraq War and Severe Acute Respiratory Syndrome (SARS) in 2003 shook the market. In 2002, JAL and JAS merged. Furthermore, the global financial crisis in 2008-9 hit the Japanese air transport market and in January $2010 \mathrm{JAL}$ went bankrupt and filed for a legal liquidation procedure. The Government bailed out JAL through a national scheme involving the Enterprise Turnaround Initiative Corporation of Japan, and in September 2012, it was re-listed on the Tokyo Stock Market. JAL retained profitability by cutting less lucrative routes.

\section{Liberalisation in the international air transport market}

An international Air Service Agreement (ASA) was renegotiated to allow multiple airlines into the market. In particular, the ASA with the USA was revised in 1998 to achieve a balance of rights between the two nations and allow for more competition. Furthermore, since October 2010, an Open Sky Agreement has been finalized, starting with the USA. As of March 2012, 15 countries, covering $67 \%$ of the international passengers to/from Japan, have concluded such agreements.

\section{New era of $L C C$}

The year 2012 marked the beginning of the low-cost carrier (LCC) era in Japan. In October 2012, the first LCC dedicated terminal was opened in Kansai Airport. The opening of Terminal 2 marked the launch of airport-airline collaboration, giving birth to the first Japanese based LCC; Peach Aviation ${ }^{8}$. There are currently two other LCCs incorporated in Japan, Air Asia Japan and Jetstar Japan, and ten foreign-based LCCs flying into Japan.

8. This development has lead LCC to become a social phenomenon in Japan and "LCC" was chosen as one of the Top 10 best vogue words for 2012. In January 2013, Kansai Airport was awarded "LCC Airport of the Year" at a convention in Singapore. 


\section{The history of airport development}

Since 1967, long-term airport construction plans were set every five years. The number of airports more than doubled, from 45 in 1975 to 98 in 2013. There are currently 65 airports with a runway length of more than 2000 metres.

Airports in Japan are classified into three categories:

1) International airports: Haneda ${ }^{9}$, Narita, Itami, Kansai and Chubu airports;

i. Special corporations:

Narita, Kansai and Chubu airports;

ii. Owned directly by the Government:

Haneda Airport.

Itami Airport, until recently government-owned like Haneda, has been integrated with Kansai Airport.

2) National airports: e.g. Sapporo, developed and operated by central government;

3) Local airports: e.g. Kobe, developed and operated by local governments ${ }^{10}$.

One distinctive characteristic of Japanese airports is that -- except for Narita, Kansai and Chubu airports -- terminal buildings are separately built and managed by private firms or third-sector corporations ${ }^{11}$. In recent years, the integration and privatization of rampsides and terminals have become part of a policy agenda and, in 2011, a law was passed that integrates Kansai and Itami airports under the New Kansai International Airport Company Ltd. (NKIAC). NKIAC is planning to acquire a third-sector terminal operator at Itami Airport. It is also stipulated under the law that NKIAC would sell the operational rights of both airports for a number of years to global investors to reduce debt. This is the first concession involving major infrastructure in Japan. Central government is planning to submit a law that enables the grant of concessions for other airports.

9. The formal name of Haneda Airport is Tokyo International Airport, but in this paper, Haneda Airport shall be used for short. Likewise, Narita Airport, Itami Airport and Kansai Airport are used instead of Narita International Airport (New Tokyo International Airport until 2004), Osaka International Airport and Kansai International Airport.

10. Apart from these three categories of civil aviation airports, there are a small number of military airports controlled by the National Defence Force and the US Air Force that allow use by commercial aircraft.

11. Land for terminal construction is leased out by the Government. 


\section{BRIEF HISTORY OF AIRPORT DEVELOPMENT IN TOKYO AND OSAKA}

\subsection{Tokyo}

\section{Early years of Haneda Airport}

Haneda Airport was one of the first three airports in Japan to be constructed. In 1931 it started off with a single runway 300 meters long and 15 meters wide. It was located 15 kilometers in direct distance away from Tokyo Station, by the mouth of the Tamagawariver, one of five major rivers flowing into Tokyo Bay. Compared to Itami Airport in Osaka which is located closer to the city center but 15 kilometers away from mouth of the Yodogawa River and Osaka Bay and locked into a place without option to develop out towards the bay area, Haneda Airport had one side of the airport open. Figure 2 describes how Haneda Airport is located and it could be seen that it is close to the city centre so the north side of the airport is restricted. It has room, however, for air space in the south side. This resulted in a totally different outcome of these two airports.

Figure 2. Airport operation at Haneda Airport

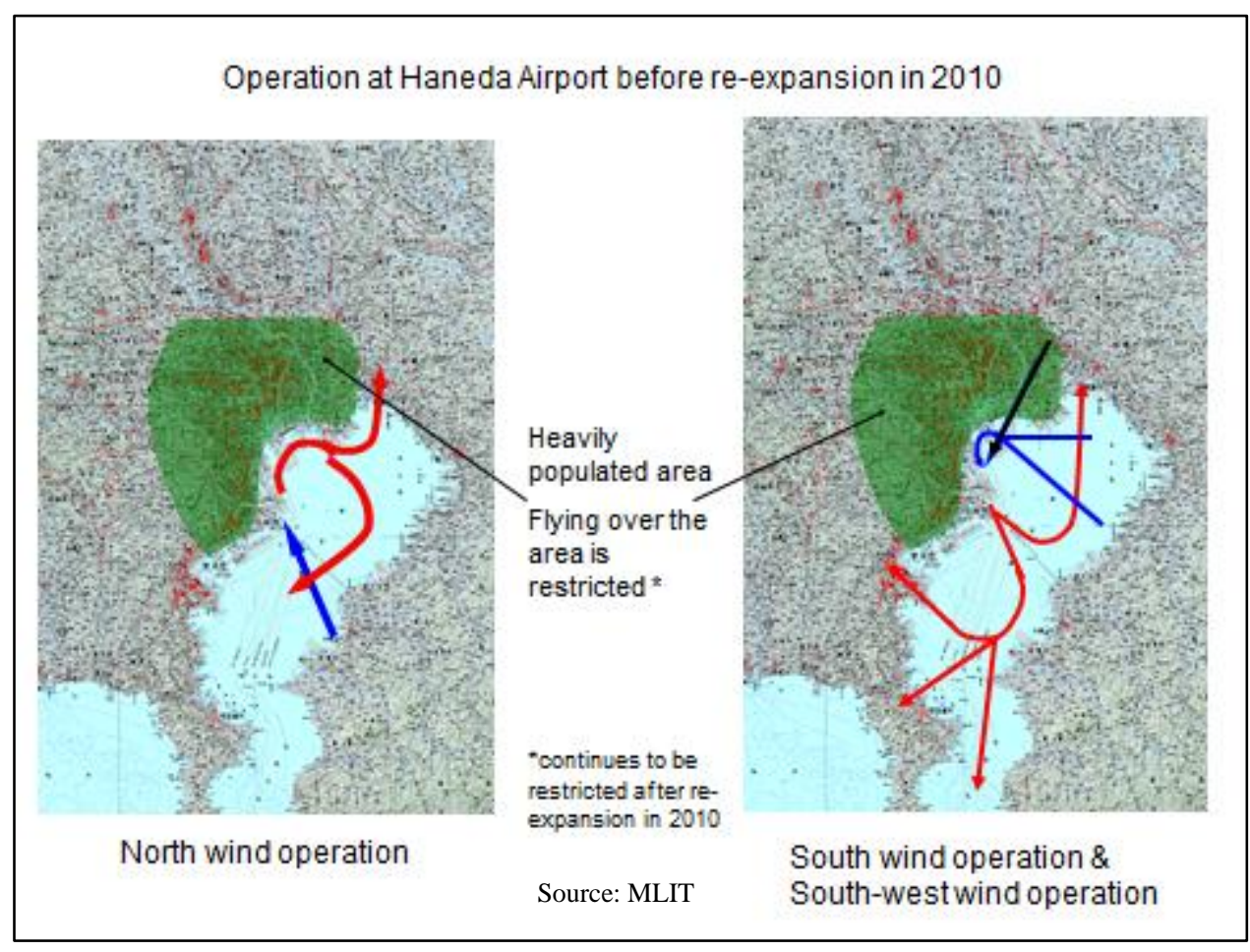


Figure 3. History of Haneda Airport

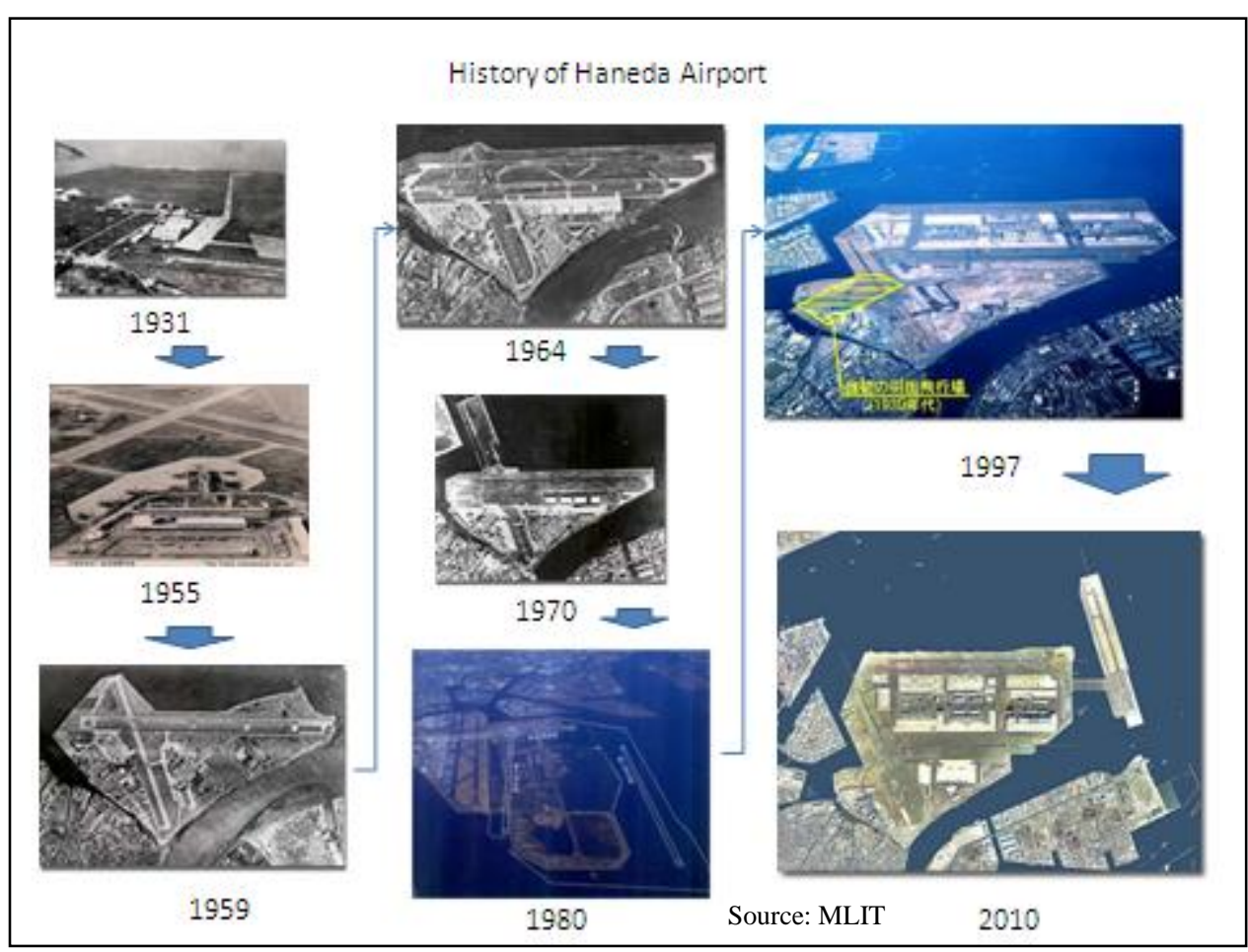

Figure 3 shows how Haneda Airport was developed. By the 1950s, Haneda Airport had two runways crossing each other; 2550 meters (Runway A-old) and 1676 meters (Runway B-old) and a new passenger terminal.

In 1964, when the Olympic Games were held in Tokyo, Runway C-old parallel to Runway A-old was built to accommodate growth in demand. Runway A-old, however, was soon necessary to be converted into aprons for aircrafts to park so that the airport was once again constrained to having only two runways. When turbo-jet aircrafts started to operate in the early 1960s, noise issue was raised in the vicinity of Haneda Airport. Although the government responded by introducing curfew between $11 \mathrm{pm}$ to 6am for turbo-jet aircrafts in 1962 and subsequently legislated subsidy for noise mitigation measures at designated nearby facilities, growing demand and noise issue mandated the government to plan a totally new airport for Tokyo.

\section{Development of Narita Airport}

In 1963, the Ministry of Transport commissioned to consider the location of the new airport. In 1965, among a number of options, the government chose the plan to build a new airport with five runways in Tomisato Village, Chiba Prefecture. This decision aroused substantial controversy at Tomisato because it was not consulted with the local residents. It was also alleged that the location was selected as a result of pork-barrel by politicians. At the end of the reviewing process that involved multiple ministers, land size was reduced by half and seeking to utilize central and local government owned land, Sanrizuka, ten kilometers north of Tomisato, was selected as the site. Again, abrupt decision was faced with strong opposition from the local land-owners, particularly from the farmers that had settled into Sanrizuka after hardship of cultivation in the past decades. Resistance of the farmers was coupled with left-wing radical activists and 
marked the beginning of long difficult history of Narita Airport development ${ }^{12}$. Figure 4 shows the history of Narita Airport development.

Government agency had proceeded to acquire land from the local owners, but was confronted with harsh resistance. Opening planned for March 1978 was blocked by unlawful raid into restricted area of the airport and even into the ATC tower by left-wing radical activists. It finally started operation in May, with its single runway that had been completed at that time. We had to wait 24 years to have the second runway operational. Land procurement law became inactive because no one assumed the position of land acquisition committee of Chiba Prefecture. Not only did acquisition of land for the second and the crosswind runway delayed, construction of jet-fuel pipeline had to wait until 1983 to be completed.

Figure 4. Development of Narita Airport

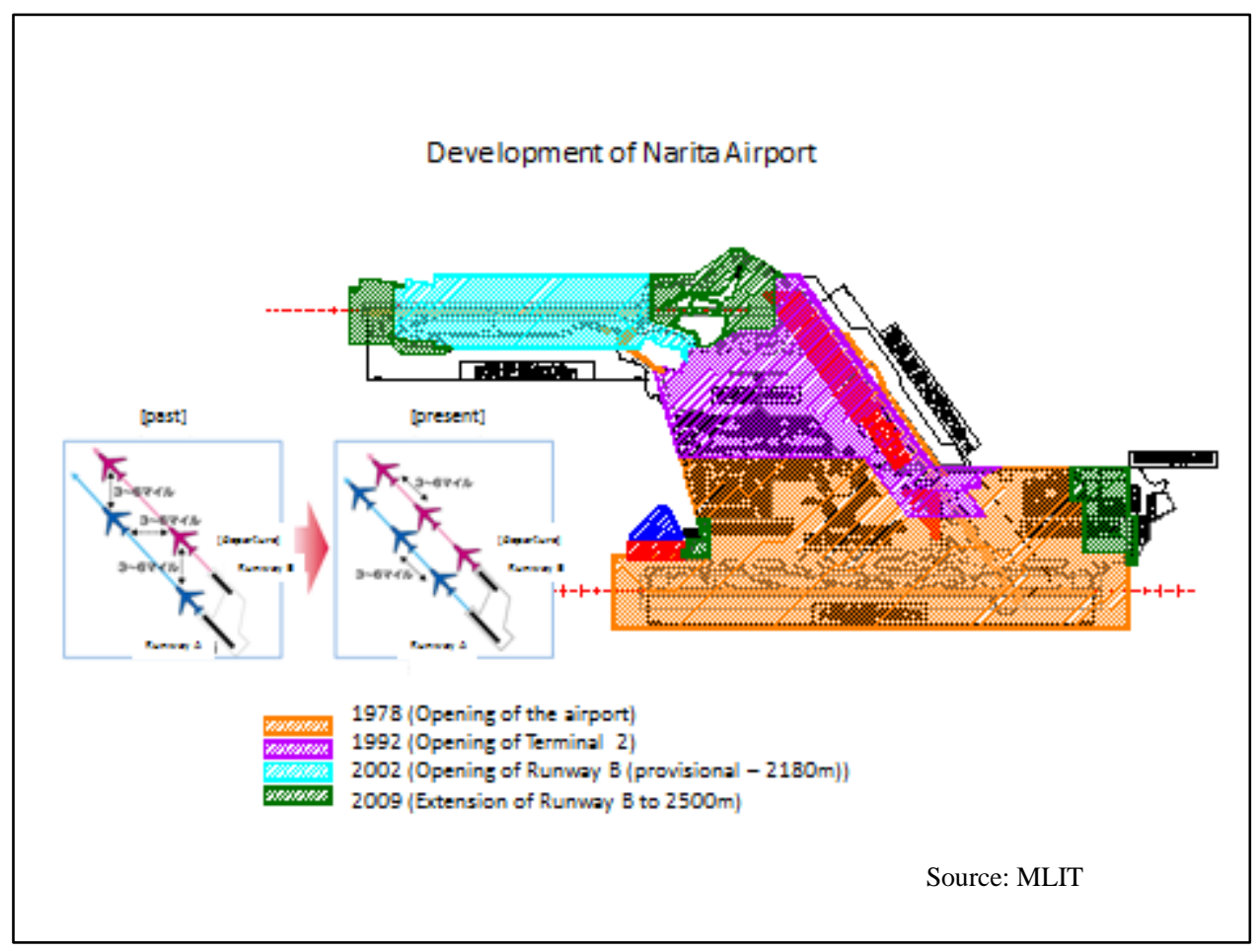

Original plan to build high-speed railway "Shinkansen" between Narita Airport and Tokyo had been rejected by Governor of Tokyo. Access railway accommodating limited express train to Tokyo Station had to wait until 1991 which took an hour to get there from Narita Airport. In 2010, one of the railways providing express service between Narita Airport and Tokyo was completed to shorten the trip to 36 minutes $^{13}$.

12. Airport planning needs to identify optimal location, which is often already used by specific entities for specific purpose. Although it is necessary to achieve consent of the existing land owners, it is also imperative to avoid arbitrary movements. Price of land sky-rockets once specific location is announced. Thus, announcement of land acquisition of specific sites for airport development requires confidentiality. This is conflicts with democratic process that asks for laying down options publicly and decided through debate.

13. It is, however, necessary to transfer to another railway and take 10 minutes ride before arriving at Tokyo Station. There is a plan to connect the line directly to Tokyo Station so that it would take the same 36 minutes to arrive at Tokyo Station from Narita Airport without transfer. 


\section{Haneda Airport expanding towards the bay area}

Bay side of Haneda Airport had been used as waste and sludge dumping site. Utilization of the site was hindered by the paste-like texture of the dump. It was not until sand and paper drainage technology was available for the dump site to be considered as area for airport expansion. In 1984 Haneda Airport "Okiai-tenkai" expansion project was initiated and a pair of parallel runway (Runway $A$ and Runway $C$ ) and a single cross-wind runway (Runway B) push out towards the Tokyo Bay was built in steps. Figure 3 shows how the expansion took place. These runway constructions were completed in 2000 which basically resolved noise issue at Ota-ku, the municipal district that the airport is located. Dependence on single crosswind runway, however, continued to be a bottleneck to capacity.

\section{Road to re-expansion and re-starting international flights at Haneda Airport}

As we approached the turn of the century, ANA which held half of the landing slots at Haneda Airport for domestic flights, lobbied to re-expand Haneda Airport, and to re-start international flights. During midnight there were rooms for additional flights so the initial step was to allow international charter flights during midnight. The idea of re-starting international flights at Haneda Airport triggered strong opposition from Chiba Prefecture where Narita Airport is located, claiming that after all the perseverance and hardship of constructing Narita Airport, it was injustice to re-start international flights at Haneda Airport.

\section{New developments at Narita Airport}

Occasional attack by the radical activists continued until the end of the $20^{\text {th }}$ Century. By the turn of the century, however, resistance from land owners had become limited. So the government decided to shift plan of the second runway to the north, and open a provisional Runway B, 2,180 meters long ${ }^{14}$. The provisional runway opened in 2002 , just before the FIFA World Cup jointly held that year in Japan and South Korea. The capacity increase in 2002 shown in Figure 5 indicates the impact of opening of Runway B at Narita Airport. It was extended north to become 2500 meters in October 2009.

14. At the southern end of Runway B, a farmer is still making his living in 2013. 
Figure 5. Increase in airport capacity at Haneda Airport and Narita Airport

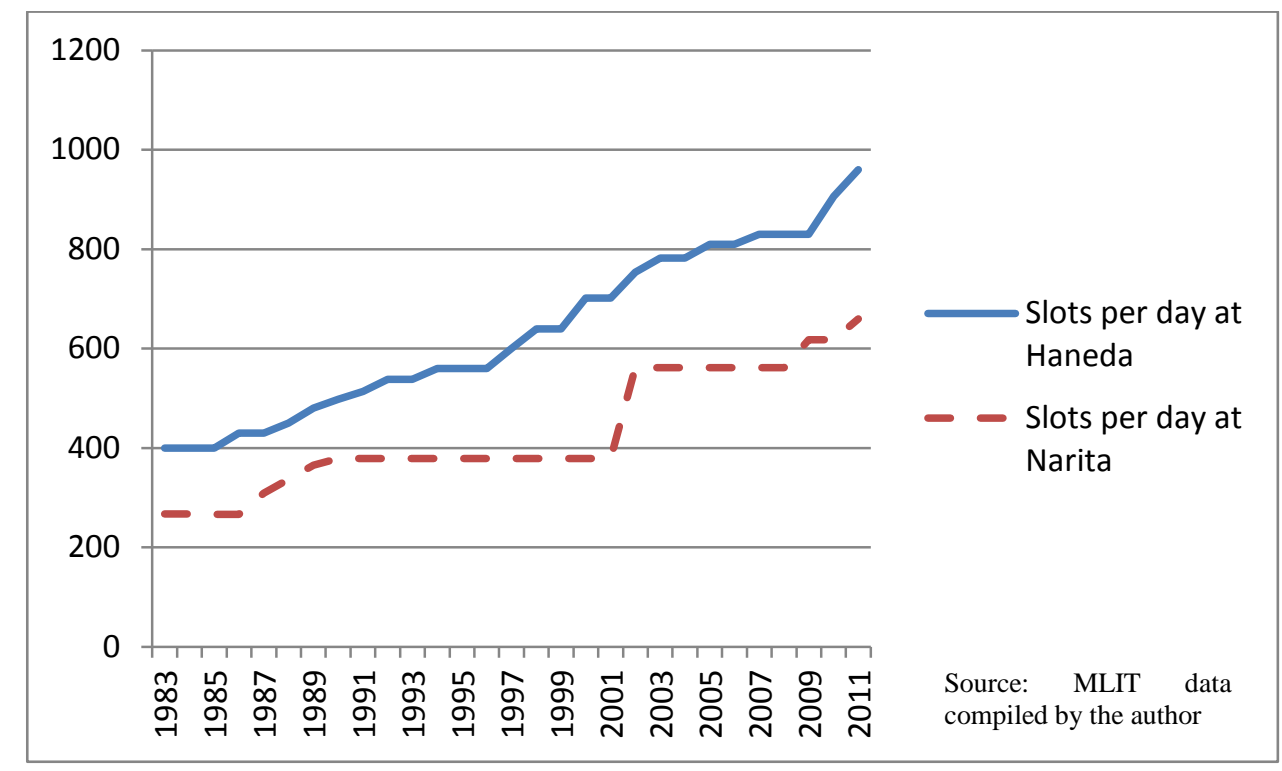

The airport was now equipped with a set of parallel runways, however, the two runways were not separate enough by normal ICAO standards to allow simultaneous take-off and landing. After thorough safety assessment and simulation, simultaneous take-off and landing was initiated in 2011. This allows for landing slots at Narita Airport to increase to 300 thousand per year, equivalent to more than 800 slots per day.

Figure 6 depicts international flights at Haneda Airport and Narita Airport as of September 2012. Haneda Airport and Narita Airport has 1825 international flights per week, of which 1451 (80\%) at Narita Airport and 374 (20\%) at Haneda Airport. At Haneda Airport, there are 224 flights at normal hours to major nearby Asian cities; Seoul Gimpo, Bejing Capital, Shanghai Hongqiao, Taipei Songshan and Hong Kong. There are also 150 flights at midnight hours connecting Haneda Airport and North America, Europe, etc.

In Table 1, a calendar of events for recent interactive development of Haneda Airport and Narita Airport is provided. 
Figure 6. International schedule flights at Haneda Airport and Narita Airport

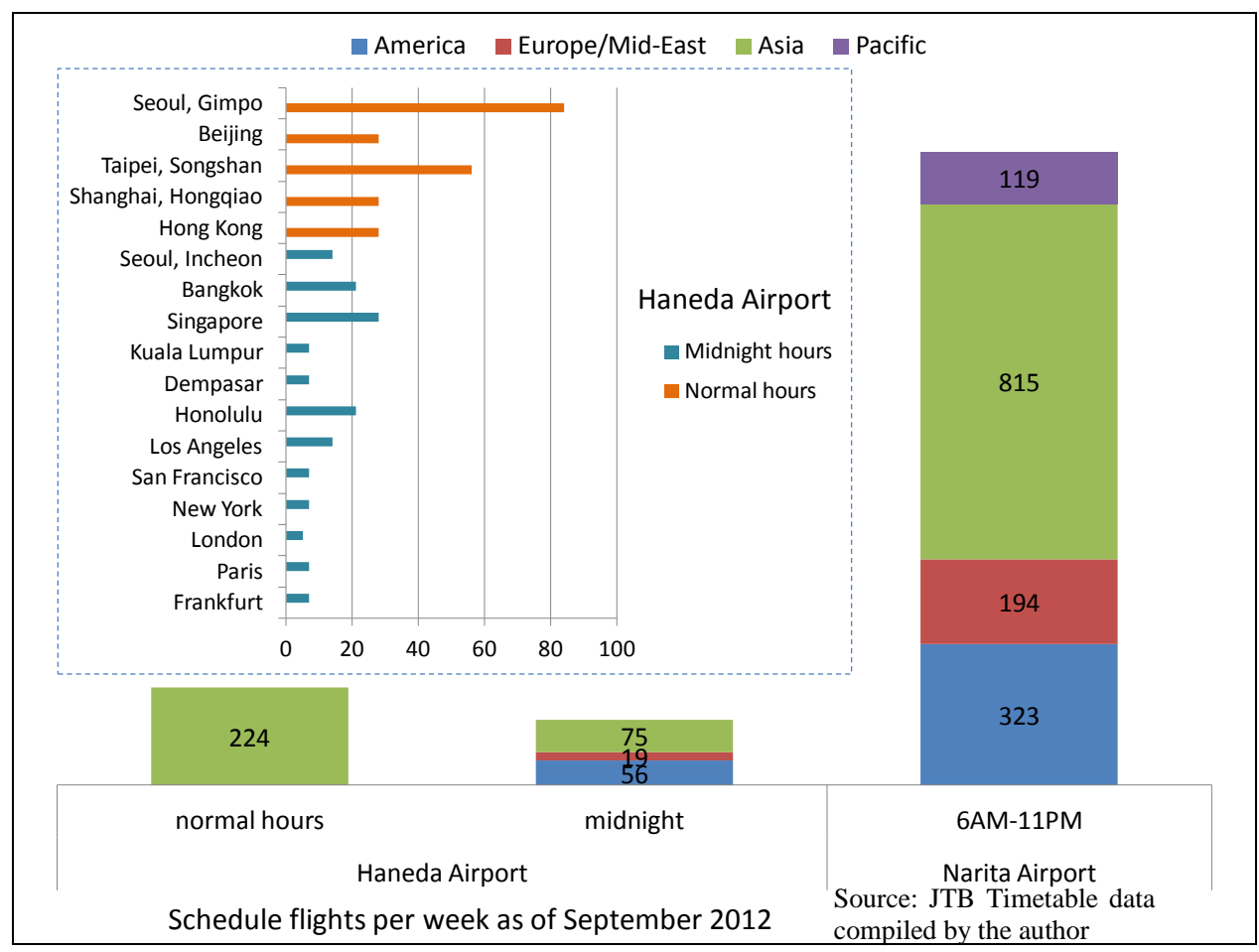

\subsection{Osaka}

\section{Itami Airport and the noise issue}

Itami Airport was opened in 1939. It had a single 1828 meter runway, until a parallel 3000 meter runway was built in 1970 when the EXPO was held in Osaka. Figure 7 shows the location of Itami Airport.

Since it was located only 11 kilometers away from CBD of Osaka and in the middle of the residential district, vicinity of the airport was infuriated with complaints against aircraft noise. In 1969, increasing noise mainly caused by growing number of turbo-jet aircrafts lead citizens to file law suits to stop evening operation and to claim for compensation. Curfew for turbo-jet aircraft between $11 \mathrm{pm}$ to $6 \mathrm{am}$ had been introduced in $1965^{15}$, and extended to $10 \mathrm{pm}$ to $7 \mathrm{am}$ in 1972 and then to $9 \mathrm{pm}$ to $7 \mathrm{am}$ in 1975. In addition to curfew, maximum number of take-off and landing per day was imposed at Itami Airport; total of 450 (out of which 260 for jet aircrafts) per day since 1971, 370 (out of which 200 for jet aircrafts) per day since $1977^{16}$.

Supreme Court's decision in 1981 rejected the claim to stop evening operation, however, endorsed government compensation for those that had suffered from noise. The court decision aroused social concerns nationwide and became a national agenda.

15. Curfew had been introduced first at Haneda Airport in 1962.

16. This slot restriction remained the same until 2013. After 36 years since introduction of this regulation, remaining 170 slots restricted to turbo-prop aircraft has been converted in steps into low-noise turbo-jet slots. 
Itami Airport marks a significant contrast with Haneda Airport where curfew was partly rescinded in 1972 by flying over the Bay of Tokyo. Since 1976, take-off from Runway Bold in Haneda Airport had been banned between 9pm to 7am, but this restriction ended when Runway B was relocated towards reclaimed area of Tokyo Bay in 2000. Itami Airport, on the other hand, still has curfew.

Figure 7. Three airports in Greater Osaka area

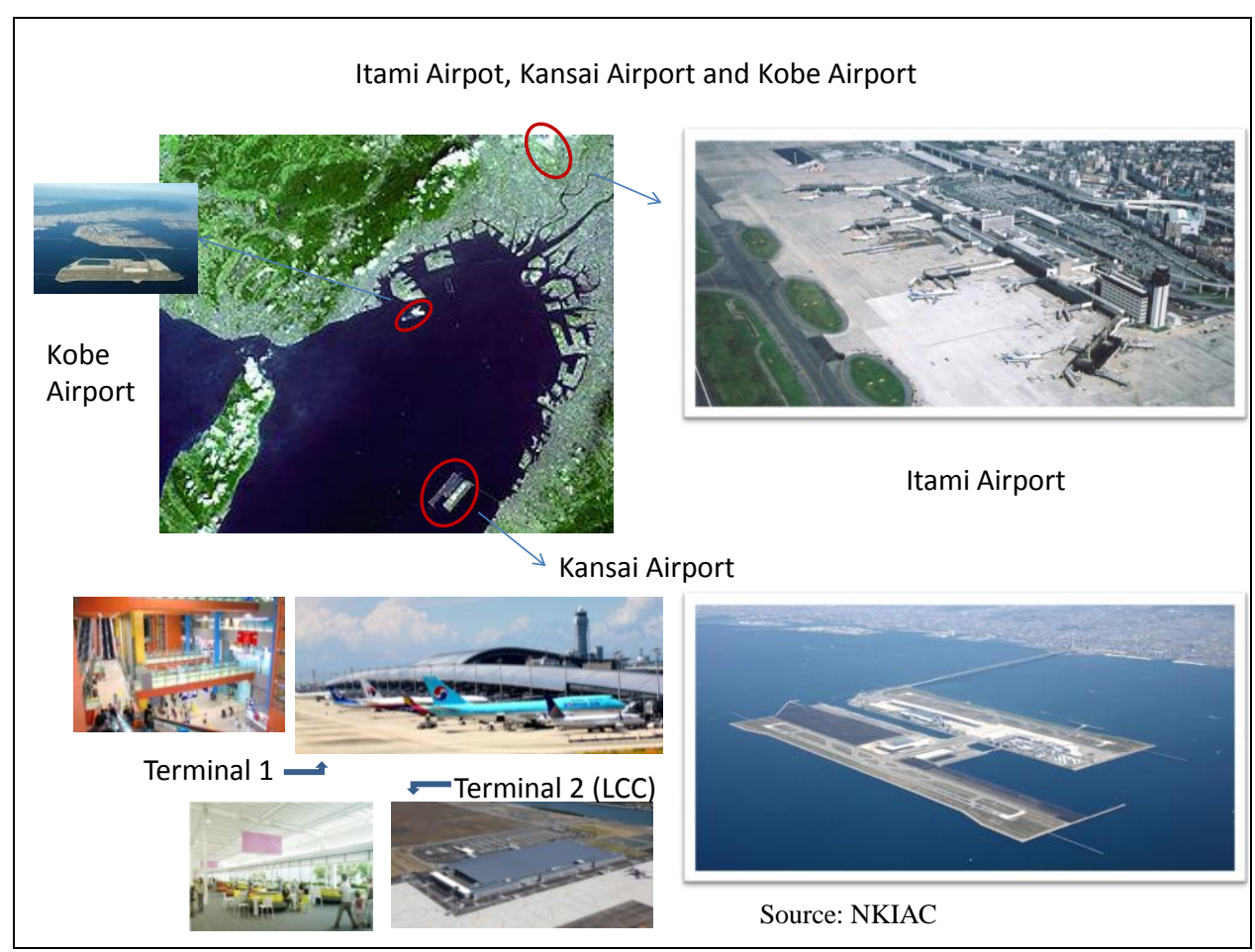

\section{Development of Kansai Airport}

In 1971, the Ministry of Transport commissioned to study the location of a new airport to accommodate growing demand at Osaka and moreover to put an end to the noise issue at Itami Airport. Planning of Kansai Airport was, in effect, crucified to resolve the environmental issue at Itami Airport. Out of the five feasible sites in the Osaka Bay area, Senshu, the most southern location and the most farther away from city centre of Osaka was selected. As shown in Figure 7, it is located 37 kilometers in direct distance and 47 kilometers by rail from the $\mathrm{CBD}^{17}$. Although it was located quite far away from heart of Osaka, there was strong opposition from citizens of Senshu so the airport was constructed on a completely reclaimed island five kilometers off the shore of Senshu.

Due to experience at Itami Airport, strong social sentiments against airport being built close to them had been embedded deeply in citizens of Osaka. In retrospect, if the plan had been initiated before nose issue at Itami Airport flared up, NIMBY sentiment may have not been as strong as it was in the 1970's. Also, advance in aircraft technology had shrunk the noise footprint by the time Kansai Airport was opened in 1994 so that it would have had been possible to build it closer to the shore.

17. Using the subway in downtown and limited express in the suburbs, it takes approximately one hour and costs about 15 US\$. 
Financial scheme of building Kansai Airport involved not only central and local governments but also private sector. This reflected trend of economic policy during 1980 's to endorse "Minkatsu", private finance initiative, in building public facilities. A single 3500 meter runway airport with a modern terminal building ${ }^{18}$ was opened in 1994 and all the international flights were transferred from Itami Airport. In 2007, 4000 meter second runway was opened to become a full-fledged international hub airport.

Although the price paid was high, building the airport away from the residential area enabled Kansai Airport to become a 24 hour-operational international airport. NKIAC was established in 2012 to integrate Kansai Airport and Itami Airport. Taking advantage of the full-fledged 24 hour-operational capability of Kansai Airport, NKIAC has taken strategic steps to facilitate start-up of Peach Aviation, Japan's first LCC, by building a LCC dedicated terminal ${ }^{19}$. Construction is currently underway to set up a new air cargo terminal for Federal Express to locate their North East Asian hub ${ }^{20}$. In order to slice down the size of debt ${ }^{21}$, government has passed a law to establish NKIAC and integrate the two major airports in Osaka in order to pool the cash-flows together, increase corporate value by strategic investment and sell the operational right of the two airports as early as FY2014.

Figure 8. Number annual take-off and landing at the three airports in Greater Osaka area ${ }^{22}$

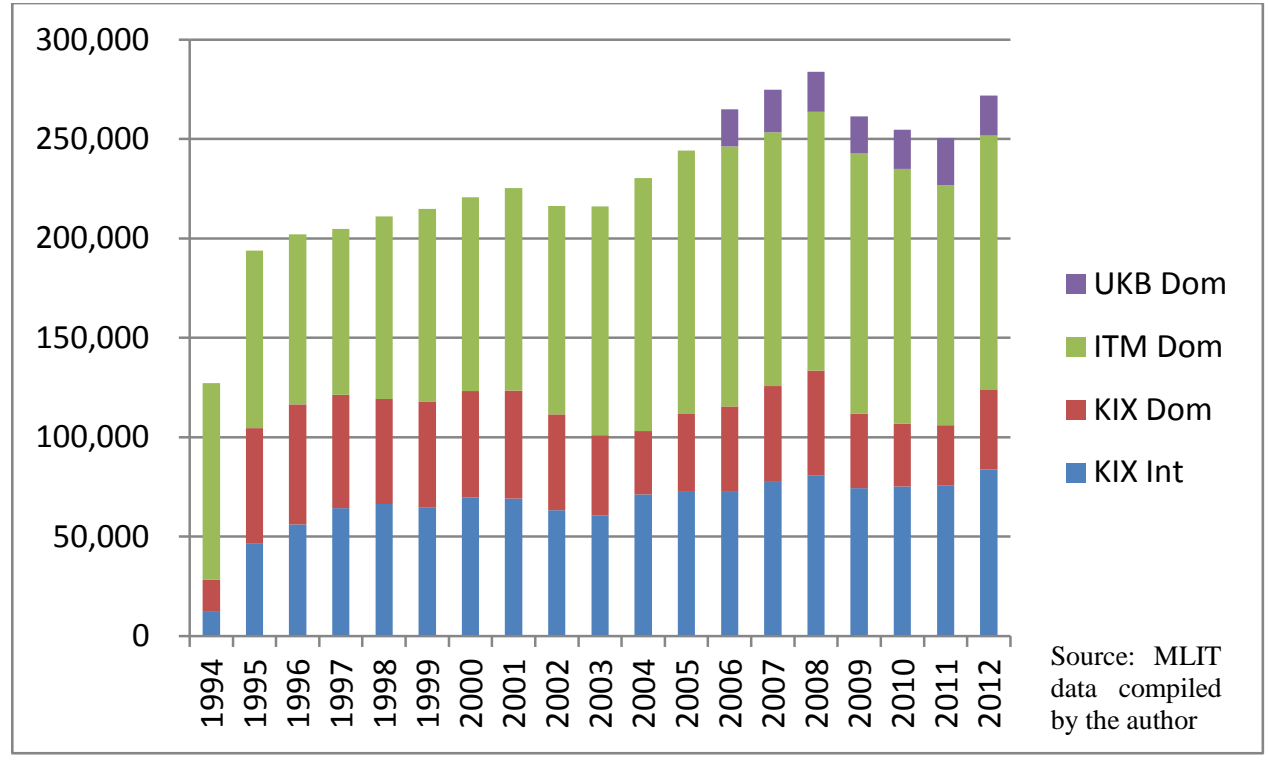

18. In 2001, American Society of Civil Engineers awarded the airport as one of ten structures given the "Civil Engineering Monument of the Millennium".

19. The year 2012 marked the beginning of LCC era in Japan. In 28 October 2012, the first LCC dedicated terminal in Japan celebrated the grand opening at Kansai Airport. Opening of the Terminal 2 (T2) was the hallmark of airport-airline collaboration to give birth to the first Japan based LCC; Peach Aviation. This development has lead LCC to become a social boom in Japan and "LCC" was chosen as one of the Top 10 for 2012 by a popular annual "best vogue word of the year award". NKIAC was also awarded "Low Cost Airport of the Year" at Budgie\$ \& Travel Award at Singapore in January 2013.

20. Kansai Airport was chosen after competition with other NEA airports.

21. As of March 2012, total debt of 14 billion US\$ is outstanding.

22. KIX, ITM and UKB stands for Kansai Airport, Itami Airport and Kobe Airport respectively. 


\section{Kobe Airport}

Back in the 1970's, Kobe was included in the five options for substituting Itami Airport, but had been rejected by City of Kobe. Following the Hanshin-Awaji earthquake in 1995 and after considerable debate among citizens, a local city airport was constructed off the shore of Port of Kobe. Different to Itami Airport and Kansai Airport that are national facilities, Kobe Airport is city owned and classified as a local airport. Due to conflict in air routes with Kansai Airport, number of take-off and landing at Kobe is limited.

International flights are not accommodated at Kobe Airport because of closeness to Kansai Airport. 


\section{KEY FACTORS AFFECTING AIRPORT DEVELOPMENT IN LARGE URBAN AREA}

\subsection{Basic nature of airport development in metropolitan area}

\section{Demand and supply function of airport}

Airport demand is a function of air transport demand, which in turn is a function of population and economic activities. Population and economic activities requires housings and offices that rely on supply of land. Land, however, is limited in urban area.

In the supply function of airport, land and air-space are the two major factors. A major characteristic of airport is its externality regarding noise caused by taking-off and landing of aircrafts. Externality of noise has graduation with respect to distance from the airport and its departure and arrival route. This gives rise to the so called NIMBY ("Not In My Back Yard") syndrome. The closer you are to the airport and its departure and arrival route, the magnitude of externality is greater.

From mobility's point of view, airport closer to the CBD would have lower access time and out-of-the-pocket cost for travel. Benefit of flying from an airport would be enhanced when the generalized cost of access to the airport is lower. So, as long as you are away from noise, the closer you are to the airport the higher the benefit. Aircraft noise correlates negatively to price of land whereas accessibility to airport positively.

\section{Large three-dimensional space needed to accommodate airport}

Tremendous amount of space is needed to accommodate safe take-off and landing of aircraft. Airborne aircraft causes wake-turbulence and the larger the aircraft the bigger the impact of wake-turbulence. Therefore, when aircrafts take-off in sequence, three to five nautical mile ${ }^{23}$ separation is required. It is the same for sequential landing of aircrafts. This amplifies capacity constraint of airport. Parallel runways, separated enough with each other ${ }^{24}$, would accommodate capacity expansion in additive manner. Building a second runway would double the capacity. But even if an airport is equipped with multiple parallel runways separate enough, capacity would be constrained if the air-space for take-off and landing is limited. For instance, if there is only one route to and from the airport that leads to high altitudes, it is as if there is only one runway.

When urban area exists in the extension of the runway, safety and noise concerns may push the path of take-off and landing away from densely populated area. An aircraft landing with instrumental procedure glides down on a three degrees slope. Under severe weather condition, it is necessary to approach the airport on the three degrees slope using ILS ${ }^{25}$ for 20 kilometers. Simple trigonometric function yields that at twelve

23. One nautical mile is 1,852 meters.

24. Under ICAO rules, No Trespassing Zone (NTZ) required for independent operation of parallel runways is 1310 meters.

25. Instrument landing system. 
kilometers away from the airport, Roppongi for instance with respect to Haneda Airport, an aircraft would glide down 630 meters above ground level; lower than twice the height of Eiffel Tower. As we have seen in Figure 2, noise concerns have historically expelled routes that fly over downtown Tokyo at Haneda Airport. Over in Osaka, aircraft approaching Itami Airport flies over CBD of Osaka, and claims that Itami Airport should be discarded has not died out.

\section{Weather conditions}

Direction of take-off and landing depends on direction of prevailing wind of the hour. Suppose you have a pair of parallel runway and a single cross-wind runway. Parallel runways need to be operational in every weather condition for scheduled flights to keep on-time. Otherwise the number of flights would be restricted to the capacity of the single cross runway. Until the fourth runway was built, Haneda Airport had accommodated flights with two parallel runways and a single cross-wind runway. Since the crosswind runway has to be used under weather condition with strong south-west wind, number of scheduled flights were capped and capacity limited.

\subsection{Overcoming the difficulties}

\section{Simultaneous planning of land-use and air-space}

In land-use market of urban area, there is tension between inhabitation and airport location. Its departure and arrival route design also has a large impact on the land beneath. This leads to the necessity to implement simultaneous planning of urban landuse and air-space design.

\section{Figure 9. Runway operation at Haneda Airport after re-expansion}

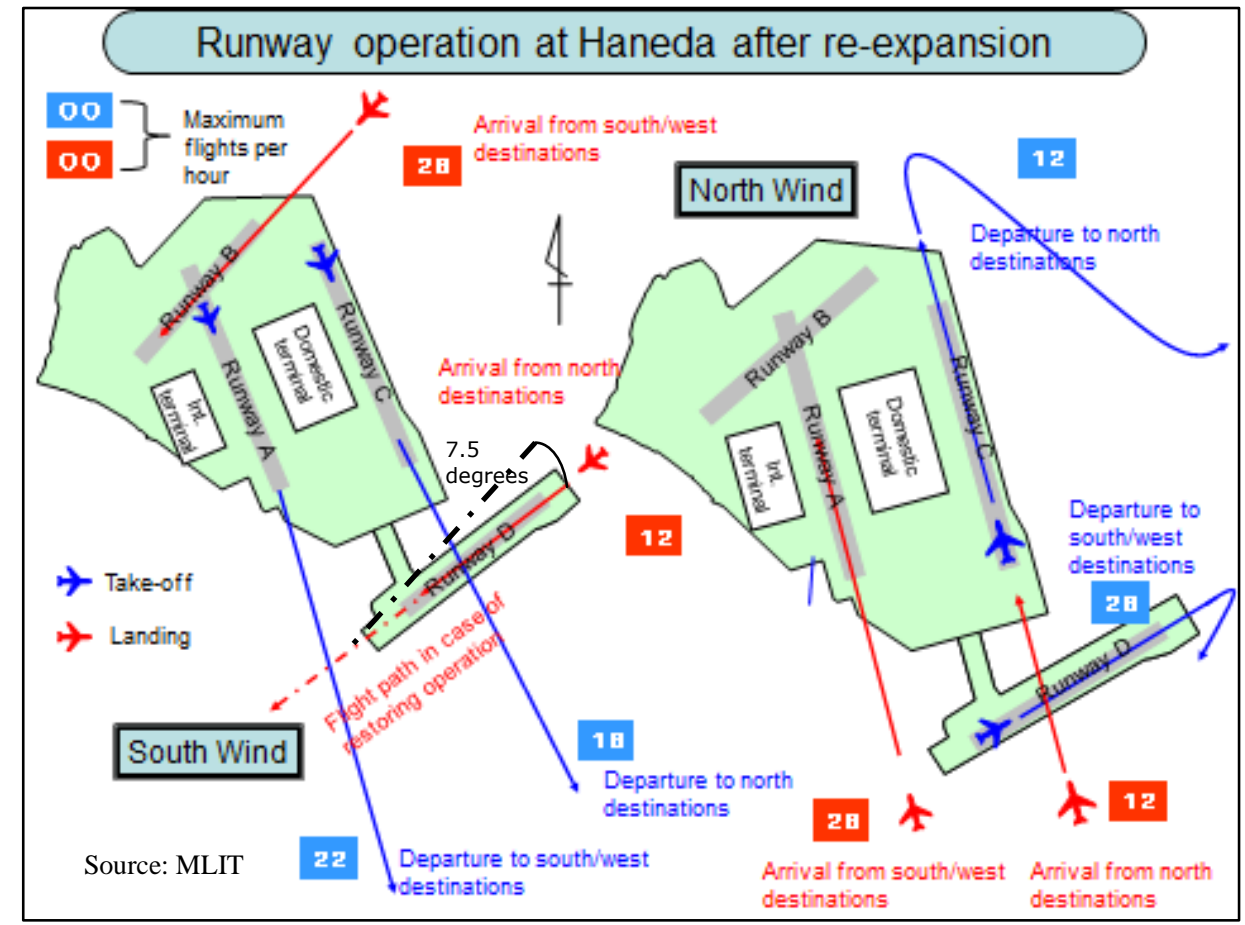

Re-expansion of Haneda Airport is full of creative arrangements. The fourth runway, Runway D, without losing the parallel position vis-à-vis Runway $B$, was tilted 7.5 degrees 
to the east and its ILS diverted 2 degrees east-ward, so that altogether of 9.5 degrees swayed towards the east in order to avoid flying over Urayasu-city, one of growing residential districts in Chiba Prefecture. (See Figure 9)

Coordination with the Yokota US Airbase that manages the west-side airspace of Tokyo was undertaken to trim the eastern edge in a step-like manner to allow aircrafts taking off from Haneda Airport to climb over Yokota airspace more easily. (See Figure 10)

Figure 10. Air space surrounding Tokyo and coordination with Yokota US Airbase

\section{Image of Airspace surrounding Tokyo}

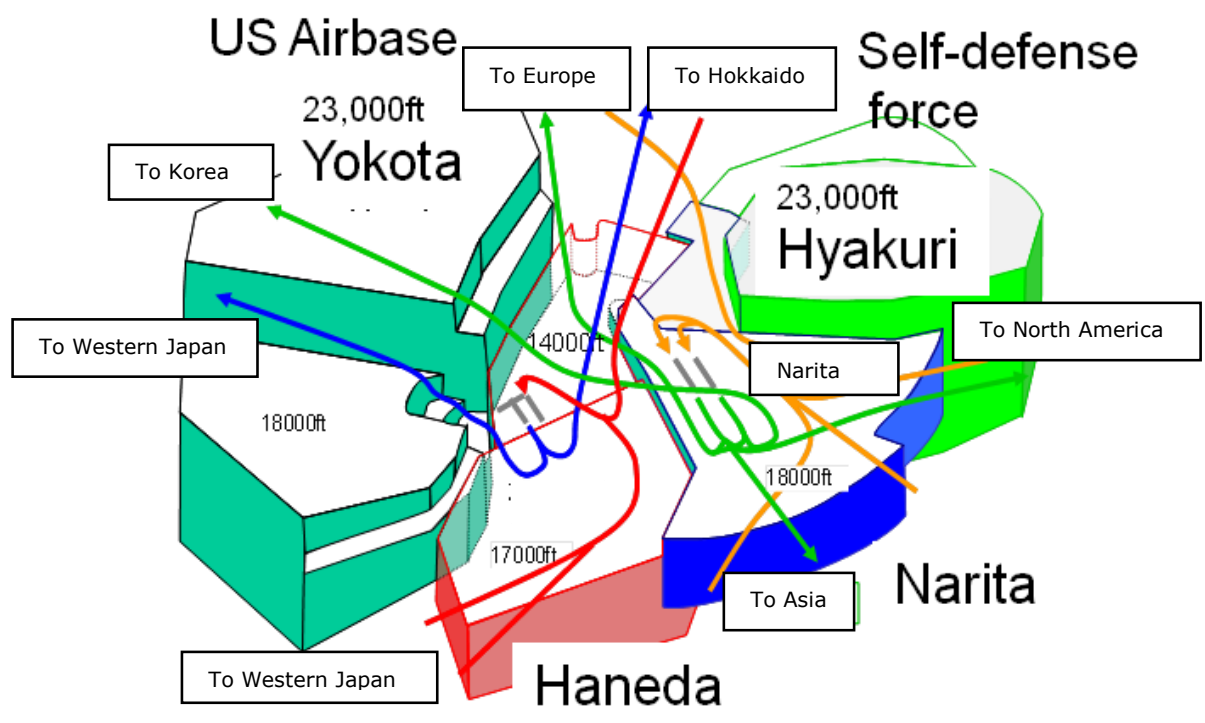

One-third of Runway D was necessary to be built protruding in the mouth of Tamagawa River. So the section that interferes with the flow of the river was designed in a bridgelike structure to allow sufficient flow of water into Tokyo Bay, while the rest of Runway D is reclaimed.

\section{Taking advantage of avionics innovations}

Cities have historically emerged in a self-organizing manner. Transport technology, on the other hand, develops at a different pace of time. Air-space management, in particular, has developed hand in hand with avionics; electronic systems installed in aircrafts composed of communication and navigation systems. Improvement of information and communication technology (ICT) is commonly time-framed by "dog-year" speed, seven times faster than human aging.

Two counter forces are at work; centripetal force to attract airport closer to the city as possible and centrifugal force of NIMBY nature to push the airport away from the city as 
possible. Unforeseeable technology advances in air-space management, has caused interface of urban planning and airport planning an extremely difficult a task to tackle.

\section{Coping with diversity of stakeholders}

Diversity of stakeholders is another factor that strongly affects decision making of airport development. Airports at major cities have nation-wide effects. Thus, central government is usually heavily involved in airport development in large urban area. Competiveness of global city is of high nation concern.

Within the central government, Treasury and Transport Ministry have diverging interests. Since airport development requires significant amount of capital outlay, Treasury pushes for involvement of local government and private sector. This makes financial arrangement for airport investment a complex task.

When source of fund depend more on the user of airport rather than on general tax payer, debt incurred for airport investment causes airport charges to be high. Servicing huge debt inhibits airport operators to adopt marginal pricing and undertake strategic pricing policies.

Local governments are heavily involved in a mixed way. They have positive interest in airport investment because accessibility to airport and thus to air transport service provides benefits to urban residents and improves productivity of business located in the metropolis. At the same time, they have to deal with noise issue. Noise issue, on the contrary, requires the local government to stand against airport development and to protect the citizens that are affected by aircraft noise. Thus, local government is often placed in a position with conflicting interests. Land-use planning is mostly managed by local government, which the residents press for both convenience and quietness of the region. So at the regional level, benefit and non-benefit coexist; benefit from accessible airports for the users and airport industries and non-benefit from the noise that airport causes for the residents in the vicinity of it.

NPOs and social activists often play roles in supporting citizens that suffer from noise. Land acquisition had been another target for them in the case of Narita Airport. Not only do they protest from environment concerns, they sometimes challenge democratic legitimacy of government action to develop airports. Experience of Narita Airport has left important lessons to be learnt.

Airlines operating at major airports also have stakes in airport development. They are strong stakeholders that lobby in the central and local government. And in many instances, different airlines have conflicting interest regarding major airport development. At Haneda Airport, for instance, ANA had historically had the lion's share of landing rights, since ANA had grown as a dominant player in the domestic market. JAL, on the other hand, had its strong presence in Narita Airport, the major international airport. So ANA pressed hard to re-expand Haneda Airport and utilize it for international flights while JAL had been opposing the idea. Influential foreign airlines also come into the picture. Historical rights of landing slots at congested airports provide room for incumbent carriers, dominant airlines in particular, to play a big role in decision making.

\section{Historical path dependence}

One of the key features of airport is that once constructed, it is basically fixed to its location. Urban area changes over time, and when the sprawl happens before the airport 
is constructed, it is not possible to wind the clock back and locate an airport beforehand. Airport development is historically path dependent.

Itami Airport was unfortunate in that it had been built in an inland area without possibility of expansion or shift-out to an area that the noise issue could be mitigated. Narita Airport is also suffering from inability to expedite acquisition of remaining land from resisting owners and also needs to cope with noise issue. At these two airports curfew still remains to be imposed.

Haneda Airport, on the other hand, is a rare case in that it had originally being built at the edge of the city facing the Tokyo Bay and gradually expanded out by reclamation. Since 1980, capacity has more than doubled. This also enabled resolving the noise issue. Although flight path during midnight hours is fixed along the Tokyo Bay and number of flights is limited, curfew has been lifted.

Kansai Airport enjoys 24-hour operation and capacity sufficient to accommodate further growth. Although, distance from the CBD and high capital cost accrued due to setting the location five kilometers off-shore cannot be modified, steps are taken to improve access transport and NKIAC is moving forward to sell the operational rights of Kansai Airport together with Itami Airport. 


\section{IMPLICATIONS FOR FUTURE AIRPORT DEVELOPMENT IN LARGE URBAN AREA}

\section{Importance of KAIZEN to the existing system}

Considering the historical path dependence of airport development, it is imperative to plan ahead of time. In global cities, such as Tokyo and Osaka, it is also necessary to improve the situation given the urban growth and airport development inherited from the past. From such perspective, it is important to undertake "KAIZEN", continuous improvement of current system, taking advantage of improvement in aircraft and avionics technology.

It is, therefore, important to identify bottlenecks and come up with a solution to resolve them. In implementing the solution it is necessary to plan carefully taking note of the critical pass that would enable the most efficient process in carrying out KAIZEN measures.

\section{Stimulating local interest groups by competitive forces among airports}

In recent years, airport competition has started to serve as catalyst. For instance, reexpansion of Haneda Airport and development of Kansai Airport have sparked local interest to be manifested at Narita Airport and Itami Airport respectively. Risk of losing out to other airport is affecting how local citizens thinking about balance between capacity growth and environment. Airport generates jobs, commercial activities, tourism, logistics activities and other positive spillover-effects, that have benefits to local residents.

\section{Improving access to/from airport}

When location of airport is set far away from city centre to avoid noise, convenience is sacrificed. One way to circumvent is to build alternative airport by reclaiming land on water. Reclamation cost, however, is high. High-speed access transport connecting the airport and CBD is also expensive. This approach of internalizing noise cost by high capital cost and high access transport cost is an attractive alternative but there is difficulty in imposing high cost to the airport users. Although it has taken considerable time, high-speed railway access to Narita Airport has improved. At Kansai Airport, significant effort has been exerted through the years to reduce cost of various modes of transport such as railway, limousine bus, ferry and automobile.

Further improvement of high-speed access transport to/from airport is of paramount importance. High-speed railway is an ideal mode of transport to develop but it is another capital intensive infrastructure that requires long-term investment. Thus, cooperation of central government, airport operator, local government and railway industry needs to be fostered. There are plans to directly connect Tokyo Station and Haneda Airport in less than 20 minutes (currently 30 minutes) and Narita Airport in 36 minutes (currently 60 minutes), and Osaka Station and Kansai Airport in 40 minutes (currently 60 minutes). 


\section{Multi-modal planning}

Domestic trunk-route transport needs to be viewed from multi-modal perspective. In Japan, Shinkansen, the high-speed railway network, has been developing since 1964. Figure 11 shows the current status of Shinkansen. As of 2012, total network of 2388 kilometers is operating and additional 780 kilometers are under construction. Superconductivity magnetic levitated super express, the so-called "Maglev", is also planned and part of it is under construction. It is planned to be connecting Tokyo and Nagoya in 40 minutes by 2027 and then to Osaka in 67 minutes by 2045. Currently between Tokyo and Osaka, the fastest Shinkansen takes 145 minutes and air transport 65 minutes. Development of high-speed rail would have substituting effect on domestic air routes, allowing capacity to be diverted to international flights. See Yamaguchi and Yamasaki (2009) for development of inter-city high-speed transport in Japan and impact of Maglev.

Figure 11. High-speed railway "Shinkansen" network

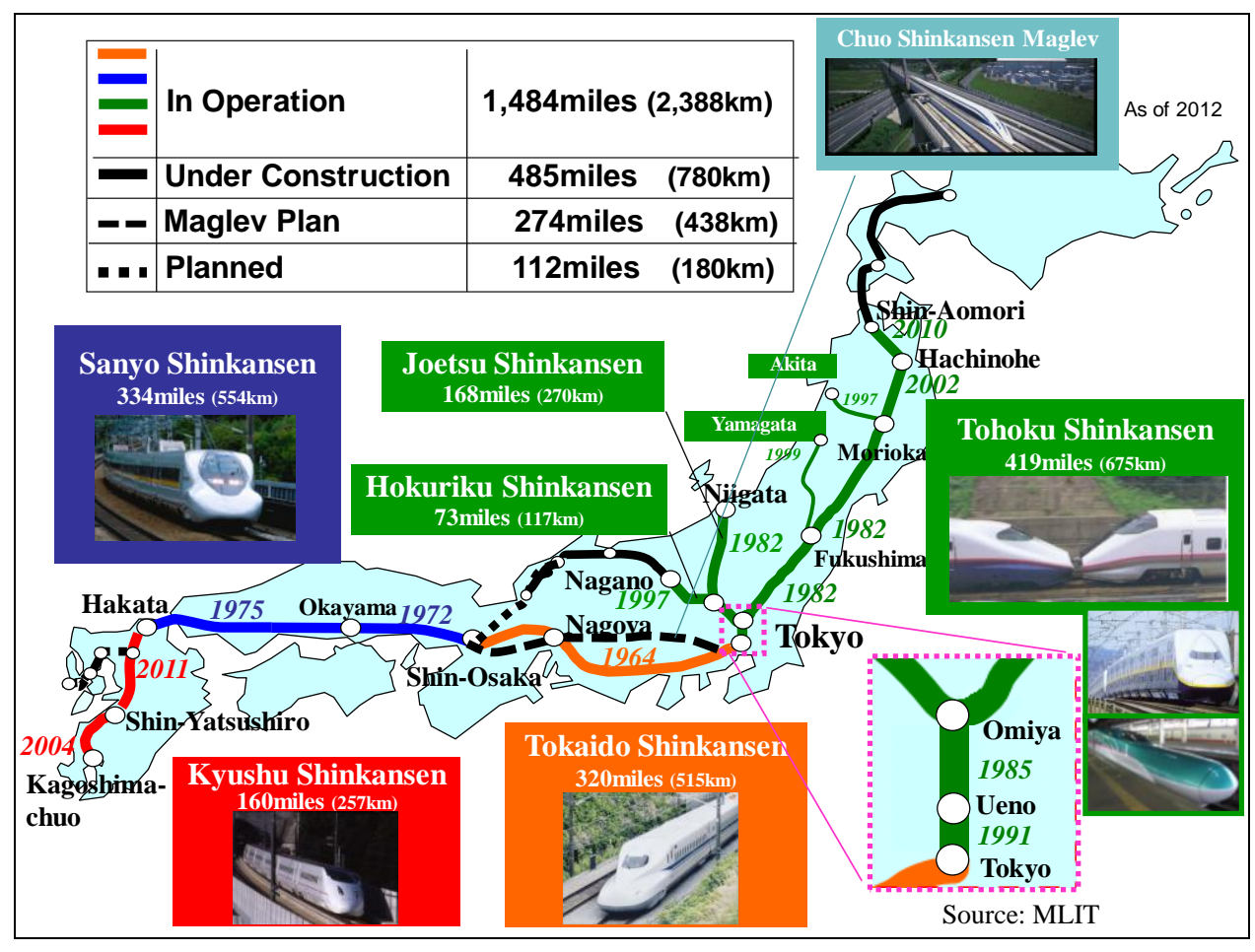

\section{Considering use of price mechanism at congested airports}

Economic theory says that congestion occurs because capacity is not priced properly. In congested airport, however, optimal market price is usually higher than cost of building and operating the airport. Airlines, however, have long claimed that landing charge and other user fee should be priced based on cost. Although it is not necessarily easy to implement the congestion pricing approach, economic efficiency and fund raising function achieved from it should be noted. 


\section{CONCLUDING REMARKS}

There is no "crystal ball" that enables airport planners to foresee the future. It is, however, possible to learn from theory and history. We have learnt from new economic geography that global cities evolve in a self-organizing matter with transport cost acting as catalyst for change. Challenging part of metropolitan airport development is to balance the market needs of the users and suppliers of air transport and the externalities that airports impose on land-use. Since there is no a priori answer or a universal pattern in deriving the solution for each metropolis, we need to enrich our knowledge of how other airports have managed and contemplate on how to make use of what we have learnt to come up with a customized break-through in the case in front of us.

\section{BIBLIOGRAPHY}

Ueda, Takayuki, A. Koike, K. Tsuchiya and K. Yamaguchi (2005), "Spatial Benefit Incidence Analysis of Airport Capacity Expansion: Application of SCGE Model to the Haneda Project" in Global Competition in Transportation Markets: Analysis and Policy Making, Research in Transportation Economics Vol. 13, Elsevier.

Yamaguchi, Katsuhiro (2007), "Inter-regional air transport accessibility and macroeconomic performance in Japan" Transportation Research Part E 43 pp.247-258, Elsevier.

Yamaguchi, Katsuhiro and K. Yamasaki (2009): "High-speed inter-city transport system in Japan -Past, present and the future -". Discussion Paper No. 2009-17, OECD/ITF Joint Research Centre. 
Table 1. Calendar of events at Haneda Airport and Narita Airport

\begin{tabular}{|c|c|c|c|}
\hline & & Haneda Airport & Narita Airport \\
\hline 1994 & October & & $\begin{array}{l}\text { Central Government and opposition groups } \\
\text { reconcile at the "Roundtable on Narita Airport } \\
\text { Issues" }\end{array}$ \\
\hline 1997 & March & Runway C opened & \\
\hline \multirow[t]{2}{*}{1998} & September & $\begin{array}{l}\text { International affinity charter to Honolulu by local } \\
\text { commercial group }\end{array}$ & \\
\hline & October & & $\begin{array}{l}\text { Capacity increased to } 135 \text { thousand annual } \\
\text { operations }\end{array}$ \\
\hline 1999 & September & & $\begin{array}{l}\text { Runway B decided to be constructed } \\
\text { provisionally at } 2170 \mathrm{~m}\end{array}$ \\
\hline 2000 & March & Runway B opened & \\
\hline 2001 & February & $\begin{array}{l}\text { International charter flights during midnight and } \\
\text { early morning allowed }\end{array}$ & \\
\hline \multirow[b]{3}{*}{2002} & April & & $\begin{array}{l}\text { Runway B (provisional) opened, capacity } \\
\text { increased to } 200 \text { thousand annual operations }\end{array}$ \\
\hline & May & $\begin{array}{l}\text { Programmed charter flights operated in daytime } \\
\text { between Gimpo (Seoul) during FIFA World Cup }\end{array}$ & \\
\hline & June & $\begin{array}{l}\text { In the Cabinet Decision Concerning Economic, } \\
\text { Fiscal and Structural Reform of 2002, following } \\
\text { clause was included: "Ministry of Land } \\
\text { Infrastructure and Transport, having prospects } \\
\text { been made to financial arrangements by relevant } \\
\text { ministries, shall re-enlarge Haneda Airport and } \\
\text { introduce international scheduled flights no later } \\
\text { than the latter half of the first decade of } 2000 . "\end{array}$ & \\
\hline 2003 & November & $\begin{array}{l}\text { Programmed charter flights operated in daytime } \\
\text { between Gimpo (Seoul) }\end{array}$ & \\
\hline 2004 & February & Domestic Passenger Terminal 2 opened & \\
\hline \multirow[t]{2}{*}{2005} & April & $\begin{array}{l}\text { Appropriation for fourth runway granted in the FY } \\
2004 \text { National Budget }\end{array}$ & \\
\hline & July & & $\begin{array}{l}\text { Runway B decided to be extended north to } \\
\text { have } 2500 \mathrm{~m} \text { in length }\end{array}$ \\
\hline \multirow{2}{*}{2007} & March & Construction of fourth runway begins & \\
\hline & September & $\begin{array}{l}\text { Programmed charter flights operated in daytime } \\
\text { between Hongqiao (China) }\end{array}$ & \\
\hline \multirow[t]{2}{*}{2008} & April & $\begin{array}{l}\text { Programmed charter flights operated in specific } \\
\text { morning-evening hours between Hong Kong } \\
\text { (China) }\end{array}$ & \\
\hline & May & Construction of International Terminal (PFI) begins & \\
\hline \multirow[t]{2}{*}{2009} & October & $\begin{array}{l}\text { Programmed charter flights operated in daytime } \\
\text { between Beijing (China) }\end{array}$ & $\begin{array}{l}\text { Runway B extended to } 2500 \mathrm{~m} \text {, capacity } \\
\text { increased to } 220 \text { thousand annual operations }\end{array}$ \\
\hline & & & $\begin{array}{l}\text { Narita Sky Access Railway opened and } \\
\text { connects to Nippori, Tokyo in } 36 \text { minutes }\end{array}$ \\
\hline 2010 & October & $\begin{array}{l}\text { The fourth runway (Runway D) and International } \\
\text { Terminal opened, and international scheduled } \\
\text { flights begin ( } 30 \text { thousand annual operations in } \\
\text { daytime and } 30 \text { thousand during midnight \& early } \\
\text { morning) }\end{array}$ & \\
\hline 2011 & October & & $\begin{array}{l}\text { Simultaneous take-off and landing procedure } \\
\text { introduced to increase capacity to } 235 \\
\text { thousand annual operations }\end{array}$ \\
\hline 2012 & March & & $\begin{array}{l}\text { Capacity increased to } 250 \text { thousand annual } \\
\text { operations }\end{array}$ \\
\hline 2013 & March & & $\begin{array}{l}\text { Capacity planned to be increased to } 270 \\
\text { thousand annual operations }\end{array}$ \\
\hline $\begin{array}{l}2015 \\
\sim\end{array}$ & & $\begin{array}{l}\text { Capacity for international flights planned to be } \\
\text { increased to } 60 \text { thousand in daytime and } 30 \\
\text { thousand during midnight \& early morning. }\end{array}$ & $\begin{array}{l}\text { Capacity planned to be increased to } 300 \\
\text { thousand operations }\end{array}$ \\
\hline
\end{tabular}


